\title{
The relationship between siblings' college choices: Evidence from one million SAT-taking families
}

\section{Citation}

Goodman, Joshua, Michael Hurwitz, Jonathan Smith, and Julia Fox. 2015. "The Relationship Between Siblings' College Choices: Evidence from One Million SAT-Taking Families." Economics of Education Review 48 (October): 75-85. doi:10.1016/j.econedurev.2015.05.006.

\section{Published Version}

10.1016/j.econedurev.2015.05.006

\section{Permanent link}

http://nrs.harvard.edu/urn-3:HUL.InstRepos:22805380

\section{Terms of Use}

This article was downloaded from Harvard University's DASH repository, and is made available under the terms and conditions applicable to Open Access Policy Articles, as set forth at http:// nrs.harvard.edu/urn-3:HUL.InstRepos:dash.current.terms-of-use\#OAP

\section{Share Your Story}

The Harvard community has made this article openly available.

Please share how this access benefits you. Submit a story.

Accessibility 


\title{
Sibling (Non) Rivalry: The Relationship Between Siblings' College Choices
}

\author{
Joshua Goodman* \\ Harvard Kennedy School \\ Michael Hurwitz* \\ College Board \\ Jonathan Smith* \\ College Board
}

June 2014

\begin{abstract}
Research consistently shows that college choice in an important predictor of college completion and labor market outcomes. These longer term implications of college choice, combined with suboptimal choices made by many low-income but high-achieving students, has sparked several large-scale initiatives to improve college choice. Strategically targeting those students most susceptible to making questionable decisions in the college-choice process remains challenging, as variation in college choice is largely unexplained by easily measurable socio-demographic characteristics. This paper explores the potential to improve upon existing models and, more generally, to better understand college choice by documenting the similarities in college enrollment patterns between younger and older siblings. To do so, we identify siblings in the millions of SAT test-takers between the 2004 and 2011 high school graduation cohorts. We find that younger siblings enroll in the same college as their older sibling 21.2 percent of the time. Also, conditional on their own SAT scores, we find that younger siblings whose older siblings enrolled in four-year colleges and the most selective colleges are 17.4 and 21.3 percentage points, respectively, more likely to themselves enroll in four-year and the most selective colleges. Overall, adding characteristics and enrollment decisions of older siblings to standard college choice models improves model fit and consequently, are valuable pieces of information for explanatory and predictive power.
\end{abstract}

*This research reflects the views of the authors and not their corresponding institutions. Authors can be contacted at joshua_goodman@hks.harvard.edu, mhurwitz@collegeboard.org, and jsmith@collegeboard.org. We thank Julia Fox for her research assistance. 
The truth is that if Princeton hadn't found my brother as a basketball recruit and if I hadn't seen that he could succeed on a campus like that, it never would have occurred to me to apply to that school, never.

--Michelle Obama

\section{Introduction}

Researchers have been modeling students' college enrollment decisions for decades (e.g. Fuller, Manski and Wise, 1982). However, it has proven a difficult modeling problem for at least three reasons. First, there are thousands of colleges, each with countless attributes, most of which are unobservable to the econometrician. Second, student preferences for attending college and the attributes of each college are heterogeneous. Third, there is substantial evidence that students don't have complete information or, at the very least, have different amounts of information (Dillon and Smith, 2013; Hoxby and Turner, 2013). Combined, this implies that the variation in college choice is left largely unexplained, or statistically speaking, the R-squared is quite low. ${ }^{1}$

The inability to effectively explain students' enrollment decisions brings up two issues. First, topics in education policy, such as affirmative action, financial aid, and degree attainment may be influenced by researchers' conclusions, which rely on these models (e.g. Long 2004a; Long 2004b; Bowen, Chingos, and McPherson, 2009). Second, there are numerous interventions aimed towards "atrisk" students (Hoxby and Turner, 2013), and identifying exactly which students are most at-risk poses a challenge if model explanatory power is weak. Consequently, improvements in explanatory and predictive power of college choice models have the potential to improve student outcomes, be it access, enrollment, affordability, or completion. This paper explores the potential to improve upon existing models and, more generally, to better understand college choice by documenting the similarities in college enrollment patterns between younger and older siblings.

To explore the enrollment patterns of siblings, we use the universe of all SAT test-takers from the 2004 thru 2011 high school graduation cohorts. Among the approximately 1.5 million students per year, we identify roughly 1.5 million sets of siblings. These data are merged with National Student Clearinghouse (NSC) data, which tracks the colleges that students enroll in. As demonstrated in Figure 1 , there is clear positive relationship between the average SAT of the college enrolled between older and younger siblings. This is even clear in Figure 2, where we account for the fact that siblings may have different abilities, but the fact remains, enrollment patterns of younger siblings frequently mirror that of older siblings. However, these figures are averages and mask a lot of information, which this paper unearths.

We start our analysis by looking at what types of students and family structures have similar enrollment patterns. We observe that 21.2 percent of siblings enroll in the exact same college. More broadly, we also observe that students enroll in the same level (two-year/four-year) 76.8 percent of the

\footnotetext{
${ }^{1}$ For example, Smith et al. (2013) models whether students undermatch and attains an R-squared of 0.161. Also, Long (2004a) highlights that one-third of the time, students in her college choice model actually attend one of the three colleges to which they are predicted to most likely attend.
} 
time. Then, using younger sibling as the unit of observation, we regress whether the younger and an older sibling have an identical application or enrollment choice on the younger sibling's demographics and academic achievements, as well as characteristics of the older sibling. We find that males, Asians and Hispanics, and students whose parents have low income and education levels are more likely to follow their sibling into the same college, compared to females, whites, and students with parents have high income and education levels. We also find that younger siblings are 2.9 percentage points more likely to enroll in the same college as their older sibling if they are of the same sex.

Next, we adopt a standard college choice model, by regressing a measure of the younger sibling's enrollment choice on her demographics and academic achievement, along with high school fixed effects. For example, we consider whether the younger sibling enrolled in a four-year college. The second specification adds characteristics of the older sibling, including sex, whether same sex as younger sibling, years between the siblings, and SAT score. The third and final specification adds whether the older sibling had an enrollment outcome similar to that of the younger sibling's outcome, for example, did the older sibling enroll in a four-year college. The progression of equations lends itself to two pieces of information. First, the coefficient estimates tell us how important the older sibling characteristics and enrollment choices are for the younger sibling. Second, the increase in R-squared demonstrates how much more of the variation in the outcome variable that older siblings' information can explain.

We find that conditional on a host of younger sibling control variables, adding the older sibling's characteristics has predictive power as to whether the younger sibling enrolls in a four year college. When an older sibling enrolls in a four-year college, the younger sibling is $\mathbf{1 7 . 4}$ percentage points more likely to enroll. Similar results hold for whether the younger sibling enrolls in a public college. We also find that the younger sibling is much more likely to enroll in a selective college, as measured by SAT scores and Barron's selectivity categories, if her older sibling does so too. Finally, we also see that younger siblings are much more likely to undermatch if their older siblings undermatch. For example, a younger sibling is $6.8,12.4$, and 16.7 percentage points more likely to enroll in a college with an average SAT score that is at least 100 SAT points lower than her own when the older sibling enrolls in a college with an average SAT that is 100, 200, and 300 SAT points lower than her own, respectively. All models are robust to multiple specifications and show modest improvements in the R-squared when including information about the older siblings.

These results make several contributions to the education literature. This is not the first paper to use siblings, but perhaps it is among the most policy relevant. There are papers that use twins and siblings when evaluating the returns to college quality, but these are typically used to account for selection issues (Ashenfelter and Krueger, 1994; Behrman, Rosensweig, and Taubman, 1996; Rouse, 1999; Lindahl and Regner, 2005; Smith, 2013). There are also papers that study the birth order effect on educational enrollment and attainment, which we briefly examine, but they often focus on differential sources of parental investment (Behrman, and Taubman, 1986; Black, Devereaux, and Salvanes, 2005; Kantarevic and Mechoulan, 2006; Booth and Key, 2009; Hotz and Patano, 2013). There are also papers that study legacy effects of a younger sibling's enrollment (e.g. Hurwitz, 2011). In contrast, this paper identifies how much predictive power in a younger sibling's college choice can be obtained from incorporating into models the older sibling's college choice. Adding these key variables to standard models may have great value for educators, counselors, and policy makers. In addition, the size and 
scope of this dataset allow us to get precise estimates at a national level, which most other datasets cannot accomplish.

\section{Data and Methods}

\subsection{Data}

This paper primarily uses two data sources. First, we use the universe of SAT test-takers in the 2004-2011 high school graduation cohorts from the College Board (CB). Every year approximately 1.5 million high school students take SAT, which is a test often required for college admissions. The test consists of two sections, math and critical reading, each graded on a scale of 200 to 800 , for a maximum possible score of $1600 .^{2}$ Along with SAT test scores the student also self-reports her high school GPA and the basic demographics, including sex, race/ethnicity, parental education and parental income. ${ }^{3}$ They also include up to 30 Score Sends, which officially reports the student's SAT score to a college, also often required for admission. Score Sends have been shown to be good proxies for college applications (Card and Krueger, 2005; Pallais 2013), but at the very least, are a good measure of student interest in a college. The data also include a student's full name, home address, and high school attended.

Second, the CB data is merged with National Student Clearinghouse (NSC) data, which collects postsecondary enrollment information on more than 94 percent of students enrolled in U.S. postsecondary institutions. ${ }^{4}$ Data from the NSC allow us observe which college, if any, a student enrolls in after high school graduation. We supplement NSC data with information from Integrated Postsecondary Education Data System (IPEDS), including whether the college is a two-year or four-year, public or private, and the average SAT of incoming students. We also include the Barron's Admissions Competitive Index of each college, which is an independent measure of selectivity. The Barron's index categorizes colleges into the following categories:

1. Most Competitive

2. Highly Competitive

3. Very Competitive

4. Competitive

5. Less Competitive

6. Noncompetitive

7. Special

The ordinal categorization is a function of SAT/ACT scores of accepted students, the admission rate, and the GPA and class rank among enrolled students. Barron's does not classify two-year colleges.

Table 1 presents the descriptive statistics of the data. 46.1 percent of the sample are males and 57.3 percent are white. Note that a large fraction of the sample have at least one parent with a bachelor's degree.

\footnotetext{
${ }^{2}$ In 2005, CB added a writing section. For continuity across the sample, and because admissions put most weight on the math and critical reading sections, we only consider those two sections.

${ }^{3}$ The self-reported variables are sometimes missing and so instead of dropping those observations, we create dummies for those instances.

${ }^{4} \mathrm{~A}$ large fraction of non-participating colleges are for-profit institutions.
} 


\subsection{Siblings}

Students do not list siblings on registration forms for the SAT, so to identify an individual's siblings in the subsequent or preceding cohorts, we developed an algorithm which identified test-takers with the same last name and home addresses. Our conservative algorithm fails to match some siblings, particularly those who may have moved residences. Furthermore, siblings graduating from high school after 2011 or before 2004 will not have been matched to sampled students from the 2004 thru 2011 high school graduation cohorts. The second set of columns in Table 1 is the descriptive statistics for younger students, the unit of observation and study in this paper. We exclude 2004 from all analyses because by construction, there are no younger siblings in 2004 and so we need not concern ourselves with older siblings (or non-siblings) in that year either other than how they influence the younger siblings.

The last row of Table 1 displays the number of identified siblings in the data. We find that the average number of siblings is 0.593 and among the younger siblings, the average size in 2.2 siblings. Note that approximately 78 percent of women in the U.S. have multiple children (Dye, 2010), so we are well short of that statistic. But this is not surprising, given our data and matching algorithm.

For comparison's sake, we also present the descriptive statistics for the oldest sibling and nonsiblings. Overall, the means are quite similar across columns, although, non-siblings have somewhat worse college enrollment outcomes than siblings, especially, relative to oldest siblings.

Finally, Table 2 shows some key variables that relate the younger sibling and an older sibling. For the older sibling, we separately examine the oldest identified sibling and the closest in age sibling, which need not be the same with sibling sets greater than two. On average, there are 2.79 years between the younger sibling and her oldest sibling. Also, they are the same gender just over half the time.

\subsection{Methods}

There are two main parts to the analysis, both using OLS. First, we examine which characteristics of the younger siblings are correlated with following an older sibling into college. The regression equation is as follows:

$$
y_{i s}=\alpha X_{i}+\beta Z_{i s}+T+H+u_{i s}
$$

where $\mathrm{y}_{\mathrm{is}}$ is an outcome for younger sibling $i$ in family s. $\mathrm{X}_{\mathrm{i}}$ is a vector of the younger sibling $i$ 's characteristics, including sex, race/ethnicity dummies, parental income and parental education dummies, high school GPA, and SAT score. $Z_{\text {is }}$ is a vector that describes the characteristics of family $s$, relative to younger sibling $i$, which includes the total years between the younger and older sibling, total number of siblings, older sibling sex, a dummy indicating whether the sex of the older sibling is the same as the sex of the younger sibling, and the older sibling's SAT scores. For most of the analyses we consider the oldest identified sibling, but show that results are robust to using the closest in age older sibling. Finally, vector $T$ represents year fixed effects and vector $H$ represents high school fixed effects, while $u_{i s}$ is an idiosyncratic error term. 
For the first analysis, we consider several outcomes, $\mathrm{y}_{\mathrm{is}}$, in order to describe younger sibling's patterns of enrollment. We start by examining whether the younger sibling applies (sends SAT scores) to the same college that the older sibling first enrolls in. Then we turn to younger sibling enrollment variables, including whether, relative to the older sibling, she enrolls in the same level (two- or fouryear), control (public or private), same Barron's category, and the exact same college. In practice, each variable is coded as a one if the application or enrollment pattern of the siblings is the same, and zero otherwise.

The second part of the analysis predicts which type of college the younger sibling enrolls in and how this college is related to the enrollment of the older sibling. The main goal of this analysis is to understand how much explanatory power the inclusion of older sibling information adds to a simple regression. Thus, most regressions in this section come in sets of three:

$$
\begin{aligned}
& y_{i s}=\alpha X_{i}+T+H+u_{i s} \\
& y_{i s}=\alpha X_{i}+\beta_{1} Z_{i s}^{1}+T+H+u_{i s} \\
& y_{i s}=\alpha X_{i}+\beta_{1} Z_{i s}^{1}+\beta_{2} Z_{i s}^{2}+T+H+u_{i s}
\end{aligned}
$$

Equation (2a) is the baseline regression that includes standard characteristics of a student, including the aforementioned demographics and academic achievement. Equation (2b) adds to equation (2a) by including attributes of the older sibling, denoted $Z_{i s}^{1}$. This tests the possibility that having a particular family structure can help predict college enrollment and whether an older sibling's academic achievement predicts something over and above the younger sibling's academic achievement. Finally, (2c) adds the variable $Z_{i s}^{2}$, which is typically the older sibling's equivalent to the outcome variable $y_{i s}$. For example, if $y_{i s}$ is whether the younger sibling enrolled in a four-year colleges, $Z_{i s}^{2}$ is whether the older sibling enrolled in a four-year college.

There are two pieces of valuable information in this second set of analyses. First, the coefficients $\beta_{1}$ and $\beta_{2}$ describe the predicted average relationship between the older sibling's information and the younger sibling's enrollment patterns. Second, we report the R-squared for each regression to document the fraction of the variation in the outcome that we can explain. It is very difficult to explain enrollment choices and we show just how much improvement in the model's predictive power can be achieved by accounting for these additional pieces of data that are absent from most analyses.

We consider a host of outcome variables in the second set of analyses. We start with college sector, hence, outcome variables include whether the younger sibling enrolls in a four-year college and then a public college. Then we examine the quality or selectivity of the college. The first outcome variable here is the average SAT of the college enrolled in, conditional on enrolling in a four-year college. The next outcome variable is a dummy variable for whether the younger sibling enrolls in a Barron's Category 1 college, the most selective. And then again for enrolling in a Barron's Category 1 or 2 college. Finally, we also predict a measure of mismatch, whereby the younger sibling enrolls in a college where the average student is far different from that of the younger sibling. This measure is constructed as the difference between the student SAT score and the college's average SAT score of incoming 
students. Hence, a positive number implies a student enrolled in a college with relatively low achieving peers, termed "undermatch," while a negative number implies the opposite, termed "overmatch." 5

Finally, we test the sensitivity of our results in several ways. First, we consider the closest in age older sibling, instead of oldest sibling. Second, we use only the younger siblings that we determine to have a single older sibling, to remove the issue of multiple older sibling pathways. Thirds, we use just 2011, a year in which we are most likely to find all older siblings. All results are robust to these choices and available upon request. Also, for all analyses, we use robust standard errors.

\section{Results}

\subsection{Which Younger Siblings Follow Their Older Siblings}

The bottom of Table 2 demonstrates the unconditional application and enrollment relationship between siblings. The younger sibling applies to the college that the oldest sibling enrolls 32.9 percent of the time, while enrolling there 21.2 percent of the time. The younger sibling also enrolls in the same level and control as the older sibling nearly three quarters of the time and in the same Barron's selectivity category almost half the time. Clearly, these unconditional relationships show that younger siblings are quite likely to follow their older siblings into college.

Table 3 presents the results from estimating Equation (1). The first column suggests that men, Asians and Hispanics, are more likely to apply to the same college as their older siblings, compared to women and whites, respectively. In terms of academic achievement, younger siblings with higher high school GPAs and SAT scores are also more likely to apply to the same college as their older sibling. In terms of family structure, the older the sibling is relative to the younger sibling, the less likely the younger sibling is to apply to the same college. Also, if there are more siblings in the family or the older sibling is of the same sex, then the younger sibling is also more likely to apply to the older sibling's college.

The next few columns show a variety of enrollment patterns. Of note, black younger siblings are 6.7 percentage points less likely to enroll in the same college as their older sibling than white students. Also, younger siblings are 2.9 percentage points more likely to enroll in the same college as their older sibling when they are of the same sex.

\subsection{Determinants of College Choice}

\subsubsection{Sector}

Table 4 displays results of Equations (2a)-(2c) where the outcomes are college sector. The ledtmost column shows a standard sector choice regression for all students in the sample. The second column adds some family structure variables. Consistent with the literature, compared to non-siblings (omitted), older siblings have slightly better educational outcomes. And here, having siblings also leads to a higher likelihood of enrolling in a four-year college. Coefficient estimates are quite similar for the next three columns, for non-siblings, oldest siblings, and younger siblings. The second column under younger siblings corresponds to Equation (2b), which includes older sibling characteristics. All the characteristics of the older siblings have coefficients that are small in magnitude. However, the next

\footnotetext{
${ }^{5}$ This terminology first appears in Bowen, Chingos, and McPherson (2009).
} 
column, corresponding to Equation (2c), predicts a coefficient on older sibling enrolling in a four-year college of 17.4 percentage points. This large in magnitude effect is much largest than most other coefficients and also increases the overall regressions explanatory power.

The next panel has similar results when exploring whether the younger sibling enrolls in a public college. Again, whether the older sibling enrolls in a public college is associated with a 24.3 percentage point increase in the likelihood of the younger sibling going to a public college.

\subsubsection{Selectivity and Competitiveness}

Table 5 runs the same analysis as Table 4 but with outcomes related to college selectivity, specifically, average SAT of the college's incoming students and whether the college is a Barron most selective college.

The baseline regression using the younger sibling shows that students with higher high school GPAs and SAT go to colleges with higher average SAT scores. In the next column, all coefficients, other than years between siblings, are statistically significant, providing evidence of the predictive power of older sibling information. In addition, an older sibling who enrolls in a college that is 100 SAT points higher than the alternative, typically has younger siblings who enroll in a college 21.7 SAT points, conditional on the younger siblings characteristics.

A similar pattern arises when the outcomes is the binary measure of attending a Barron's category 1 college, the most selective. In fact, as the last column of the table shows, only students who have an older sibling who enrolled in the most selective colleges have a meaningfully large coefficient (21.3 percentage points). Beyond that, even an older sibling who attends a slightly less selective college has a much lower chance of enrolling in the most selective colleges.

\subsubsection{Mismatch}

Table 6 assesses the likelihood of a younger sibling mismatching-enrolling in a college that is academically superior or inferior to that of the student. Mismatch typically requires information on admissions, but we abstract from that and simply look at the difference between a student's SAT and college's average SAT.

Focusing on the younger sibling, as in other tables, the R-squared of the regressions increases as more older sibling characteristics are included. Specifically, the when the difference between the older sibling and college SAT score increase by 100 points (undermatch), then the younger sibling enrolls in a college that is 17.7 SAT points below her own. This linear specification may mask some of the nuances, so the next set of results discretizes the dependent and independent measures of match.

We find that the three measure of undermatch (the positive outcomes), are all statistically more likely when the older sibling undermatches and much less likely when the older sibling overmatches. Similarly, the younger sibling is much more likely to overmatch when the older sibling does so.

\section{Conclusion}

This paper shows that younger siblings are likely to follow in the footsteps of their older siblings and consequently, older siblings are great predictors of younger siblings' college choices. This paper does not find the causal effect of an older sibling's enrollment choice on a younger sibling's choice. We 
cannot disentangle the family effect, such as wealth, culture, and thoughts on education, from the effect of the older sibling going to a certain college. This is not an important issue in this paper, since we are merely interested in the predictive value of the older sibling. However, estimating the causal effect of the older sibling's choice is a topic that deserves more attention and research.

\section{References}

Ashenfelter, O. and A. Krueger (1994). "Estimates on the Return to Schooling From a New Sample of Twins," American Economic Review. 84: 1157-1173.

Behrman, J., M. Rosensweig, and P. Taubman (1996). "College Choice and Wages: Estimates Using Data on Female Twins," The Review of Economics and Statistics. 78(4): 672-685.

Behrman, J., and P. Taubman (1986). "Birth Order, Schooling, and Earnings," Journal of Labor Economics. 4: S121-45.

Black, S, P. Devereaux, and K.Salvanes (2005). "The More the Merrier? The Effect of Family Size and Birth Order on Children's Education." Quarterly Journal of Economics. 120(2): 669-700.

Booth, A. and H.J. Kee (2009). "Birth order matters: the effect of family size on educational attainment". Journal of Population Economics. 22, 367-397.

Bowen, W.G., Chingos, M., and McPherson, M. (2009). Crossing the finish line. Princeton, NJ: Princeton University Press.

Card, D. and A. Krueger (2005). "Would the Elimination of Affirmative Action Affect Highly Qualified Minority Applicants? Evidence From California and Texas," Industrial and Labor Relations Review, 56: 416-434.

Dillon, E. and J. Smith (2013). "The determinants of mismatch between students and colleges," NBER Working Paper \#19286.

Dye, J. (2010). "Fertility of American Women: 2008," Current Population Reports, November 2010. U.S. Census Bureau.

Fuller, W. C., Manski, C. F., and Wise, D. A. (1982). New evidence on the economic determinants of postsecondary schooling choices. Journal of Human Resources, 17(4): 477-498.

Hotz, J. and J. Patano (2013). "Strategic Parenting, Birth Order and School Performance," NBER Working Paper \#19542.

Hoxby, C., and S. Turner (2013) "Expanding College Opportunities for High-Achieving, Low Income Students," SIEPR Discussion Paper No. 12-014.

Hurwitz, M. (2011). "The impact of legacy status on undergraduate admissions at elite colleges and universities," Economics of Education Review. 30(3): 480-492. 
Kantarevic, J., Mechoulan, S. (2006). "Birth order, educational attainment, and earnings: an investigation using the PSID," Journal of Human Resources. 41, 755-777.

Lindahl, L., H. Regner. (2005). “College Choice and Subsequent Earnings: Results Using Swedish Sibling Data," Scandinavian Journal of Economics, 107(3): 437-457.

Long, B.T. (2004a). "Does the Format of a Financial Aid Program Matter? The Effect of State In-Kind Tuition Subsidies," Review of Economics and Statistics. 86(3): 767-782.

Long, M. (2004b). "College Applications and the Effect of Affirmative Action," Journal of Econometrics. 12:319-42.

Pallais, A. (2013). "Small Differences that Matter: Mistakes in Applying to College," NBER Working Paper \#19480.

Rouse, C. (1999). "Further Estimates of the Economic Return to Schooling From a New Sample of Twins," Economics of Education Review. 18(2): 149-157.

Smith, J. (2013). "Ova and Out: Using Twins to Estimate the Educational Returns to Attending a Selective College," Economics of Education Review, 36: 166-180. 


\section{Figure 1}

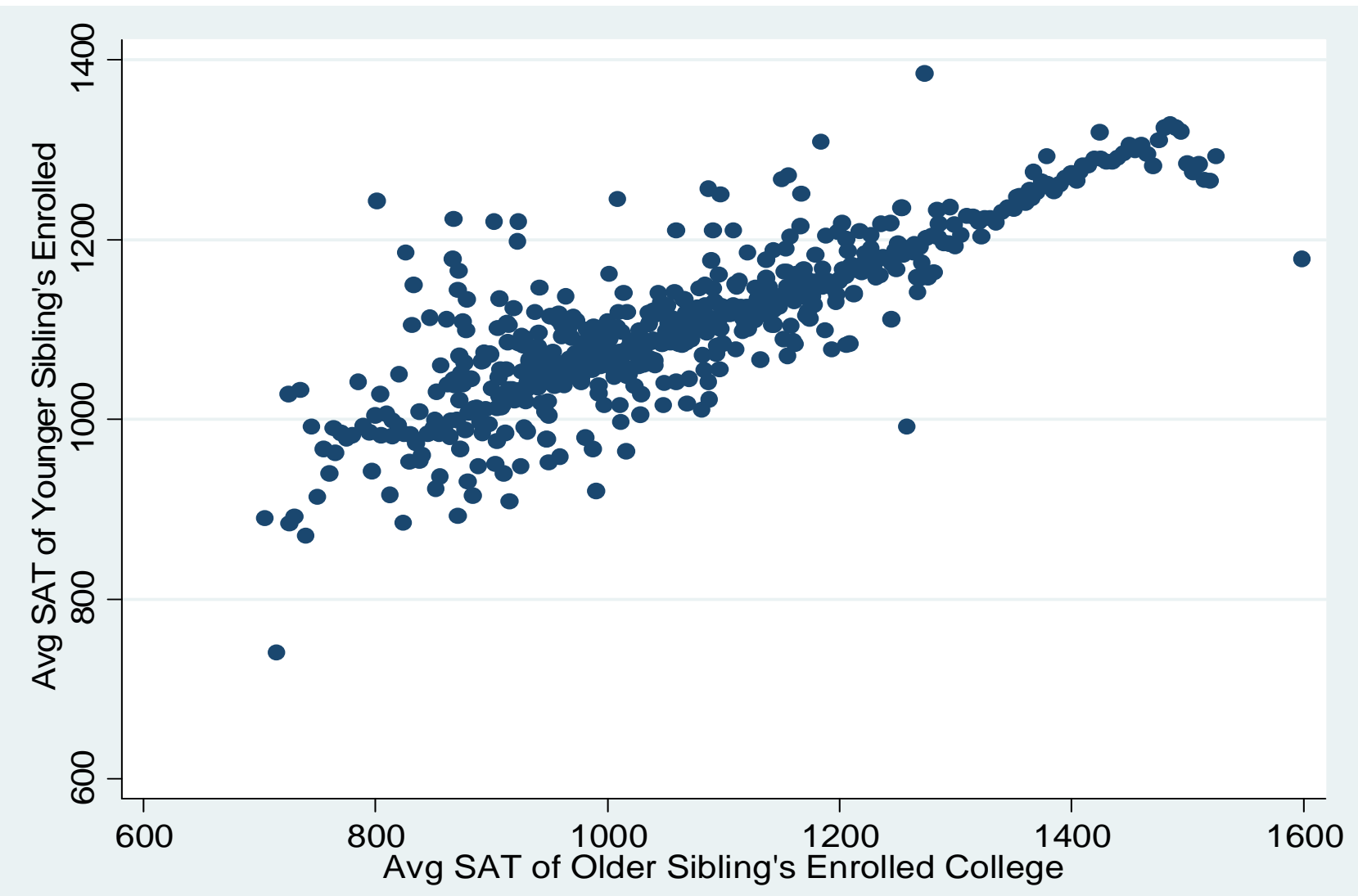




\section{Figure 2}

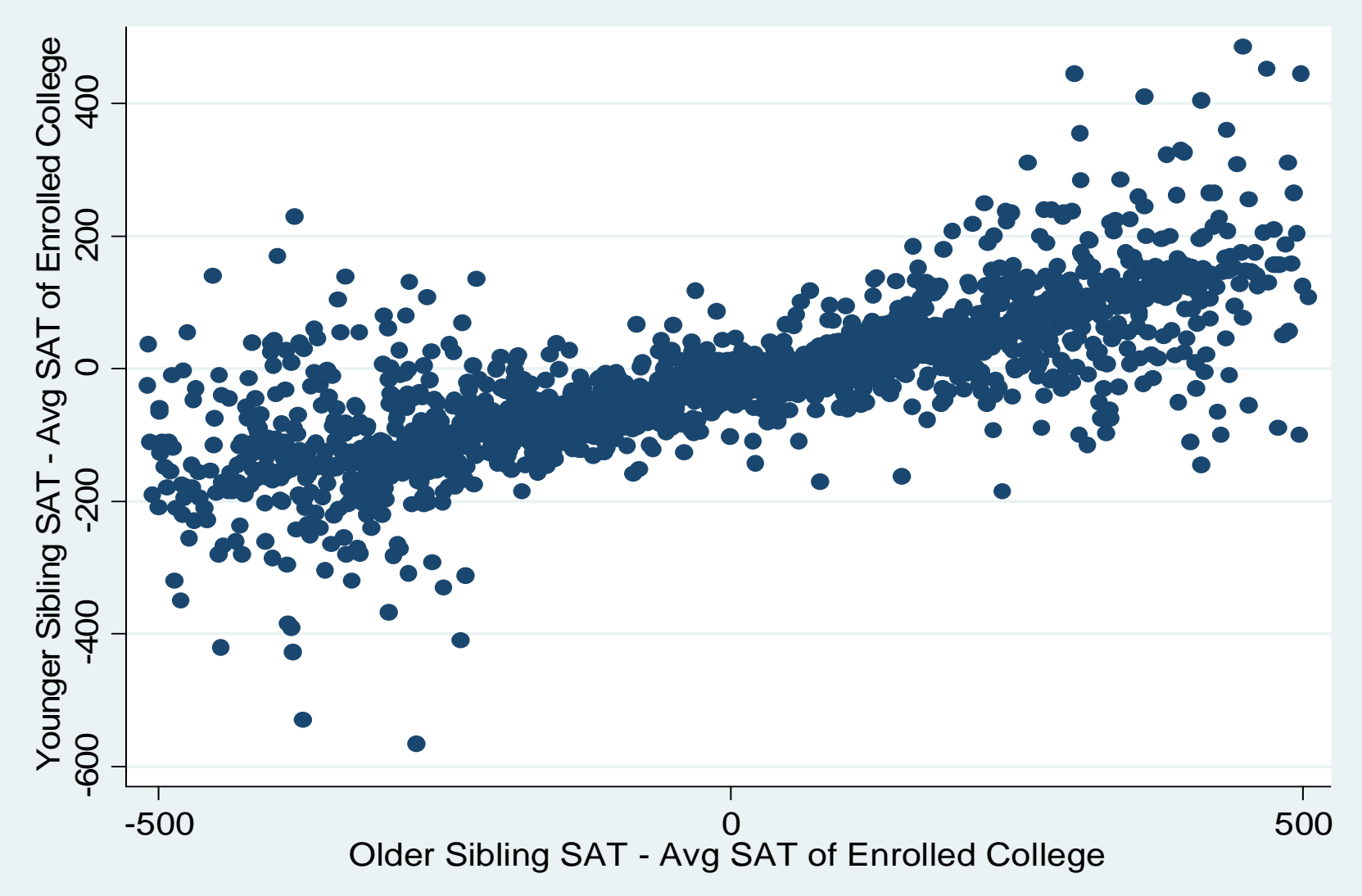


Table 1 - Summary Statistics

Male

Female

Missing Gender

Asian

Black

Hispanic

White

Other Race

Missing Race

Parental Income - Less Than $\$ 50,000$

Parental Income - $\$ 50,000$ - $\$ 100,000$

Parental Income - More Than $\$ 100,000$

Missing Parental Income

Parental Education - High School or Less

Parental Education - Some College

Parental Education - Associates Degree

Parental Education - Bachelor's or Higher

Missing Parental Education

High School GPA*

SAT (Math + Critical Reading)

Enrolls in Two-Year College

Enrolls in Four-Year College

Enrolls in Public College

Enrolls in Private College

Enrolls in For-Profit College

Enrolls in Barron's Category 1 College

Enrolls in Barron's Category 1 or 2 College

No School

Avg. SAT of Enrolled College

Student SAT - Avg. SAT of Enrolled College

Number of Siblings
All Students (obs $=10,044,488$ )

Mean
0.461
0.538

0.538

0.001

0.087

0.119

0.119
0.128
0.573

0.573

0.037

0.057

0.193

0.208

0.152

0.447

0.164

0.141

0.141

0.104

.490

0.102
3.323

3.323

0.280

0.720

0.720

0.740

0.252

0.008

0.092

0.252

0.105

0.593

\begin{tabular}{c} 
Std. Dev. \\
\hline 0.499 \\
0.499 \\
0.027 \\
0.281 \\
0.324 \\
0.334 \\
0.495 \\
0.190 \\
0.231 \\
0.394 \\
0.406 \\
0.359 \\
0.497 \\
0.370 \\
0.348 \\
0.305 \\
0.500 \\
0.302 \\
0.624 \\
210 \\
0.449 \\
0.449 \\
0.439 \\
0.434 \\
0.090 \\
0.289 \\
0.434 \\
0.307 \\
132 \\
147 \\
0.986 \\
\hline
\end{tabular}

Younger Siblings (obs $=1,614,007$ )

$\begin{array}{cc}\text { Mean } & \text { Std. Dev. } \\ 0.478 & 0.500 \\ 0.522 & 0.500 \\ 0.000 & 0.020 \\ 0.087 & 0.282 \\ 0.065 & 0.246 \\ 0.093 & 0.290 \\ 0.682 & 0.466 \\ 0.031 & 0.174 \\ 0.042 & 0.200 \\ 0.109 & 0.311 \\ 0.198 & 0.398 \\ 0.204 & 0.403 \\ 0.490 & 0.500 \\ 0.108 & 0.311 \\ 0.112 & 0.315 \\ 0.090 & 0.285 \\ 0.603 & 0.489 \\ 0.087 & 0.282 \\ 3.390 & 0.596 \\ 1055 & 198 \\ 0.219 & 0.413 \\ 0.781 & 0.413 \\ 0.711 & 0.453 \\ 0.284 & 0.451 \\ 0.004 & 0.066 \\ 0.099 & 0.299 \\ 0.275 & 0.446 \\ 0.079 & 0.269 \\ 1130 & 127 \\ -23 & 141 \\ 2.209 & 0.458 \\ & \end{array}$

Oldest Siblings (obs $=1,146,476$ )

$\frac{\text { Std. Dev. }}{0.500}$

Non-Siblings (obs $=7,284,005$ )

$0.490 \quad 0.500$

0.500

$\begin{array}{ll}0.509 & 0.500 \\ 0.001 & 0.024\end{array}$

$\begin{array}{ll}0.001 & 0.024 \\ 0.087 & 0.282\end{array}$

$\begin{array}{ll}0.065 & 0.247 \\ 0.094 & 0.292\end{array}$

$\begin{array}{ll}0.094 & 0.292\end{array}$

$0.654 \quad 0.476$

$\begin{array}{ll}0.035 & 0.184 \\ 0.065 & 0.247\end{array}$

$\begin{array}{ll}0.065 & 0.247 \\ 0.159 & 0.366\end{array}$

$0.269 \quad 0.443$

$0.216 \quad 0.412$

$0.356 \quad 0.479$

$\begin{array}{ll}0.356 & 0.307 \\ 0.115 & 0.319\end{array}$

$\begin{array}{ll}0.115 & 0.319 \\ 0.094 & 0.291\end{array}$

$\begin{array}{ll}0.094 & 0.291 \\ 0.590 & 0.492\end{array}$

$0.096 \quad 0.295$

$3.414 \quad 0.596$

$1075 \quad 204$

$0.200 \quad 0.400$

$0.800 \quad 0.400$

$\begin{array}{ll}0.695 & 0.460 \\ 0.300 & 0.458\end{array}$

$\begin{array}{ll}0.300 & 0.458 \\ 0.005 & 0.072\end{array}$

$\begin{array}{ll}0.113 & 0.317\end{array}$

$0.299 \quad 0.458$

$\begin{array}{ll}0.060 & 0.237\end{array}$

1136

-11
2.087

128

144
0.298

\begin{tabular}{c} 
Mean \\
\hline 0.453 \\
0.546 \\
0.001 \\
0.087 \\
0.139 \\
0.141 \\
0.535 \\
0.039 \\
0.058 \\
0.217 \\
0.200 \\
0.130 \\
0.453 \\
0.185 \\
0.152 \\
0.108 \\
0.449 \\
0.106 \\
3.293 \\
998 \\
0.307 \\
0.693 \\
0.754 \\
0.236 \\
0.010 \\
0.086 \\
0.237 \\
0.119 \\
1111 \\
-35 \\
0 \\
\hline
\end{tabular}

$\frac{\text { Std. Dev }}{0.498}$

0.498

$\begin{array}{ll}0.546 & 0.498 \\ 0.001-0.028 & 0.281\end{array}$

$\begin{array}{ll}0.001 & 0.028 \\ 0.087 & 0.281\end{array}$

$0.139 \quad 0.346$

$\begin{array}{ll}0.141 & 0.348 \\ 0.535 & 0.499\end{array}$

$0.039-0.194$

$0.217 \quad 0.412$

$0.200 \quad 0.400$

$0.130 \quad 0.337$

$\begin{array}{ll}0.130 & 0.498 \\ 0.185 & 0.388\end{array}$

$0.152-0.359$

0.359

$\begin{array}{ll}0.449 & 0.497\end{array}$

$0.106 \quad 0.308$

$3.293 \quad 0.632$

$\begin{array}{ll}211 \\ 0.307 & 0.461\end{array}$

$0.693-0.461$

$0.754-0.431$

0.731

$\begin{array}{ll}0.236 & 0.425 \\ 0.010 & 0.098\end{array}$

$0.086 \quad 0.280$

$0.237 \quad 0.425$

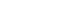

$-35 \quad 149$

Notes: Sample includes all SAT test-takers from the 2005-2011 high school graduation cohorts.

Indicates missing observations. 


\begin{tabular}{|c|c|c|c|c|c|c|}
\hline Younger Siblings Only (Primary Sample) & & lest Sibl & & \multicolumn{3}{|c|}{ Closest Sibling } \\
\hline Number of Years Between Sibling & $\overline{1,614,007}$ & $\overline{2.791}$ & 1.385 & $\overline{1,614,007}$ & 2.575 & 1.241 \\
\hline Same Gender as Sibling & $1,612,652$ & 0.511 & 0.500 & $1,612,591$ & 0.511 & 0.500 \\
\hline Applies to Same College as Sibling & $1,517,115$ & 0.329 & 0.470 & $1,517,205$ & 0.331 & 0.471 \\
\hline Enrolls in Same Level (2/4 Year) as Sibling & $1,409,518$ & 0.768 & 0.422 & $1,409,717$ & 0.768 & 0.422 \\
\hline Enrolls in Same College as Sibling & $1,409,629$ & 0.212 & 0.409 & $1,409,830$ & 0.215 & 0.411 \\
\hline
\end{tabular}




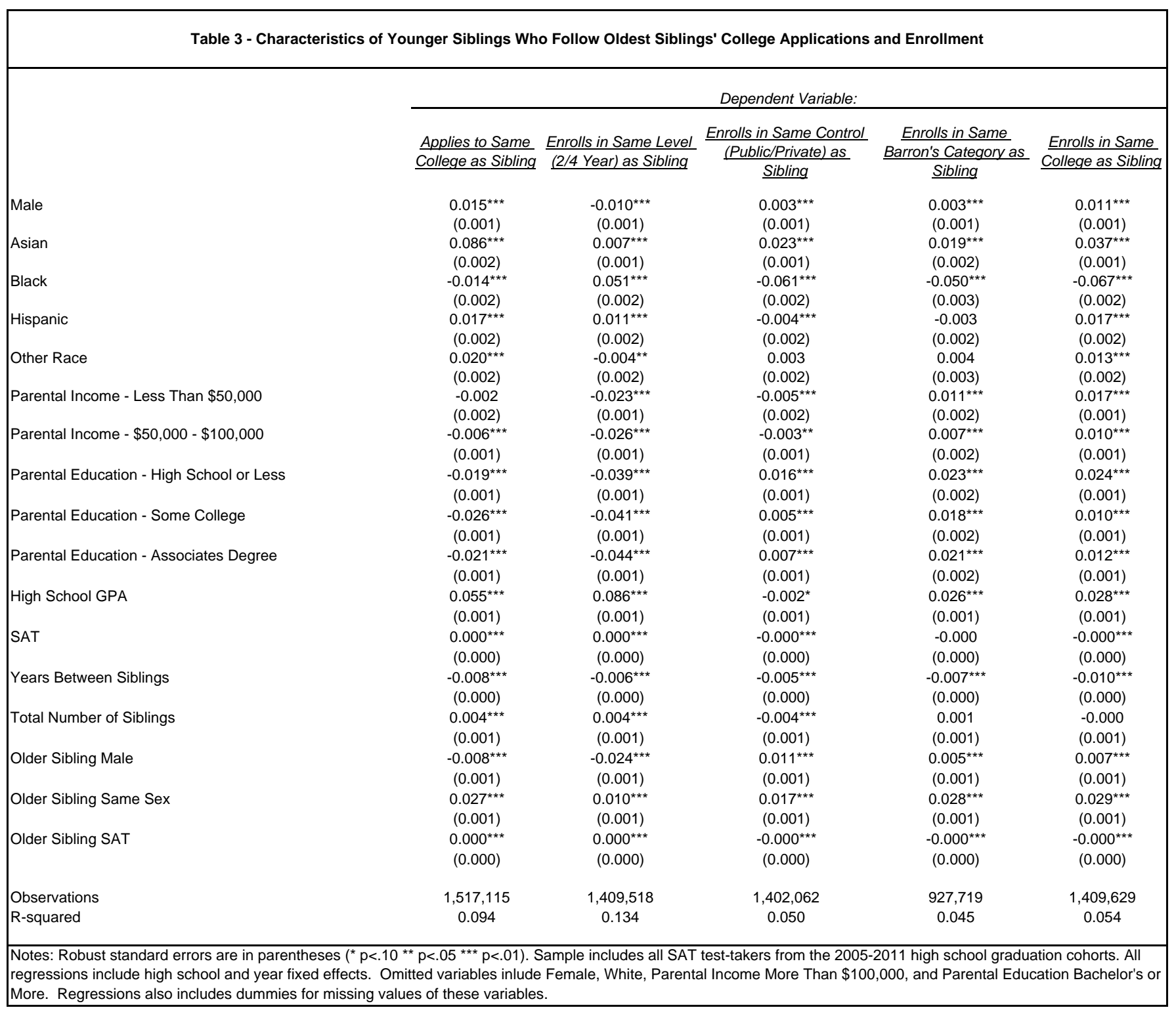




\begin{tabular}{|c|c|c|c|c|c|c|c|c|c|c|c|c|c|c|}
\hline \multirow[b]{4}{*}{ Male } & \multicolumn{14}{|c|}{ Table 4 - Determinants of College Sector } \\
\hline & \multicolumn{7}{|c|}{ Dependent Variable = Enrolls in Four-Year College } & \multicolumn{7}{|c|}{ Dependent Variable = Enrolls in Public College } \\
\hline & \multicolumn{2}{|c|}{ All Students } & \multirow{2}{*}{ 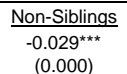 } & \multirow{2}{*}{$\begin{array}{c}\frac{\text { Oldest Siblings }}{-0.032^{\star \star \star *}} \\
(0.001)\end{array}$} & \multicolumn{3}{|c|}{ Younger Siblings } & \multicolumn{2}{|c|}{ All Students } & \multirow{2}{*}{ 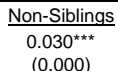 } & \multirow{2}{*}{ 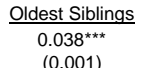 } & \multicolumn{3}{|c|}{ Younger Siblings } \\
\hline & $\begin{array}{c}-0.030 * \star * \\
(0.000)\end{array}$ & $\begin{array}{c}-0.030^{* \star \star *} \\
(0.000)\end{array}$ & & & $-0.036^{\star \star \star *}$ & $-0.036^{* \star *}$ & $-0.039^{\star \star *}$ & $0.032^{\star \star \star}$ & $0.032^{\text {t*k }}$ & & & $0.039^{* * *}$ & $0.038^{\star * *}$ & $0.040^{* \star \star *}$ \\
\hline Asian & $0.013^{+*+}$ & $0.013^{\star \star \star}$ & $0.016^{\star \star \star}$ & & $0.006^{\star \star \star x+}$ & $0.006^{\star \star \star *+}$ & $0.004^{\star \star \star}$ & $0.026^{\star \star \star}$ & $0.026^{\star \star \star}$ & $0.022^{\star \star \star}$ & $0.035^{\star \star \star}$ & $0.033^{\star \star \star}$ & $0.033^{\star \star \star *}$ & $\left.0.025^{\star \star \star}\right)$ \\
\hline & $(0.001)$ & $(0.001)$ & $(0.001)$ & $(0.001)$ & $(0.001)$ & $(0.001)$ & $(0.001)$ & $(0.001)$ & $(0.001)$ & $(0.001)$ & $(0.002)$ & $(0.001)$ & $(0.001)$ & $(0.001)$ \\
\hline Black & $0.120^{* k+k}$ & $0.123^{\star \star \star}$ & $0.131^{\star \star \star *}$ & $0.098^{\star \star \star}$ & $0.102^{\star \star \star *}$ & $0.104^{\star \star \star}$ & $0.091^{\star \star \star \star}$ & $-0.079^{* \star *}$ & $-0.079^{\star \star \star *}$ & $-0.078^{\star \star \star}$ & $-0.081^{\star \star \star}$ & $-0.079^{* * *}$ & $-0.084^{\star \star \star *}$ & $-0.067^{\star \star \star}$ \\
\hline Hispanic & -0.000 & $0.001^{\star}$ & $0.004^{\star \star \star}$ & 0.001 & $-0.003^{\star \star}$ & -0.002 & $-0.003^{*}$ & $-0.015^{* \star *}+1$ & $-0.015^{\star \star \star x}$ & $-0.014^{\star \star \star}$ & $-0.016^{* \star \star}$ & $-0.019^{* *+k}$ & $-0.021^{\star \star *}$ & $-0.017^{\star \star \star}$ \\
\hline & $(0.001)$ & $(0.001)$ & $(0.001)$ & $(0.002)$ & $(0.001)$ & $(0.001)$ & $(0.001)$ & $(0.000)$ & $(0.000)$ & $(0.001)$ & $(0.002)$ & $(0.001)$ & $(0.001)$ & $(0.001)$ \\
\hline Other Race & $0.003^{* * *+}$ & $0.004^{\star \star * *}$ & $0.008^{\star \star \star}$ & $-0.004^{*}$ & $-0.006^{\star \star \star \star}$ & $-0.006^{\star \star \star *}$ & $-0.005^{\star \star \star}$ & $-0.006^{\star \star \star}$ & $-0.006^{\star \star \star}$ & $-0.008^{\star \star \star}$ & -0.002 & 0.001 & -0.000 & -0.000 \\
\hline & $(0.001)$ & $(0.001)$ & $(0.001)$ & & $(0.002)$ & $(0.002)$ & $(0.002)$ & $(0.001)$ & $(0.001)$ & $(0.001)$ & $(0.002)$ & $(0.002)$ & $(0.002)$ & $(0.002)$ \\
\hline Parental Income - Less Than $\$ 50,000$ & 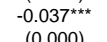 & $-0.035^{\star * *}$ & $-0.037^{\star \star * *}$ & $-0.032^{\star \star * *}$ & $-0.028^{\star \star *}$ & $-0.028^{\star \star \star}$ & $-0.023^{\star \star \star}$ & $0.003^{\star \star \star}$ & $0.002^{\star \star \star}$ & $0.003^{\star \star \star}$ & $0.003^{* *}$ & 0.001 & -0.000 & 0.001 \\
\hline Parental Income - $\$ 50,000-\$ 100,000$ & & $(0.000)$ & $(0.001)$ & & & $(0.001)$ & $(0.001)$ & $(0.001)$ & $(0.001)$ & $(0.001)$ & $(0.002)$ & $(0.001)$ & $(0.001)$ & $(0.001)$ \\
\hline Parental Income - $\$ 50,000$ - $\$ 100,000$ & $-0.030^{+*+1}$ & $-0.029^{\star * * *}$ & $-0.030^{* * *}$ & $-0.026^{* * *}$ & $-0.031^{\text {t*kt}}$ & $-0.031^{\star \star \star \star}$ & $-0.026^{\text {tat }}$ & $0.010^{0+k+k}$ & $0.010^{* * * *}$ & $0.010^{\star \star \star \star}$ & $0.013^{\star \star \star *}$ & $0.007^{\star \star \star}$ & $0.006^{\star \star \star}$ & $0.005^{\star \star \star}$ \\
\hline Parental Education - High School or Less & $-0.057^{\star \star \star *}$ & $-0.055^{* \star *}$ & $\begin{array}{l}\left.-0.054^{\star \star \star}\right) \\
-(0)\end{array}$ & $\begin{array}{l}(0.001) \\
-0.049^{* * *}\end{array}$ & $\begin{array}{l}-0.057^{\star \star *} \\
-(0)\end{array}$ & $\begin{array}{l}(0.001) \\
-0.055^{\star * *}\end{array}$ & $\begin{array}{l}(0.001) \\
-0.047^{\star \star *}\end{array}$ & $\begin{array}{l}(0.000) \\
0.026^{* * \star}\end{array}$ & $\begin{array}{l}(0.000) \\
0.026^{* * *}\end{array}$ & $0.001)$ & $0.001)$ & $(0.001)$ & $(0.001)$ & $(0.001)$ \\
\hline & $(0.000)$ & $(0.000)$ & $(0.001)$ & $(0.002)$ & $(0.001)$ & $(0.001)$ & $(0.001)$ & $(0.000)$ & $(0.000)$ & $(0.000)$ & $(0.001)$ & $(0.001)$ & $(0.001)$ & $(0.001)$ \\
\hline Parental Education - Some College & $-0.048^{+* 0 \times}$ & $-0.046^{* * * *}$ & $-0.047^{\star \star *}$ & $-0.039 * * * x$ & $-0.050^{* *+*}$ & $-0.049^{* * *}$ & $-0.041^{\star \star \star *}$ & $0.024^{* * *}$ & $0.023^{* k+\alpha}$ & $0.023^{*+* x}$ & $0.021^{\star \star \star}$ & $0.024^{\star \star \star}$ & $0.021^{\star \star \star \star *}$ & $0.016^{* \star \star}$ \\
\hline Parental Education - Associates Degree & $\begin{array}{l}(0.000) \\
-0.050^{\star \star *}\end{array}$ & $\begin{aligned} & (0.0000) \\
-0.049 * * & -1\end{aligned}$ & $\begin{array}{c}(0.001) \\
-0.049^{\star \star \star}\end{array}$ & $\begin{array}{l}(0.001) \\
-0.042^{\star \star \star}\end{array}$ & $\begin{array}{l}(0.001) \\
-0.053^{\star * \star}\end{array}$ & $\begin{array}{l}(0.001) \\
-0.052^{\star \star *}\end{array}$ & $\begin{array}{l}(0.001) \\
-0.043^{\star \star \star *}\end{array}$ & $\begin{array}{l}(0.000) \\
0.026^{\star * \star}\end{array}$ & $\begin{array}{l}(0.000) \\
0.025^{\star \star \star}\end{array}$ & $\begin{array}{l}(0.000) \\
0.025^{\star * *}\end{array}$ & $\begin{array}{l}(0.001) \\
0.023^{\star \star \star}\end{array}$ & $\begin{array}{l}(0.001) \\
0.029^{\star \star \star}\end{array}$ & $\begin{array}{l}(0.001) \\
0.025^{\star \star *}\end{array}$ & $\begin{array}{l}(0.001) \\
0.019^{* * *}\end{array}$ \\
\hline & $(0.000)$ & $(0.000)$ & $(0.001)$ & $(0.001)$ & $(0.001)$ & $(0.001)$ & $(0.001)$ & $(0.000)$ & $(0.000)$ & $(0.001)$ & $(0.001)$ & $(0.001)$ & $(0.001)$ & $(0.001)$ \\
\hline High School GPA & $0.145^{\star \star \star *}$ & $0.144^{\star \star \star \star}$ & $0.146^{\star \star \star}$ & $0.137^{\star \star \star \star}$ & $0.143^{\star \star \star}$ & $0.143^{\star \star \star \alpha}$ & $0.139^{* \alpha *}$ & $-0.059^{* * *}$ & $-0.059^{\star \star \star}$ & $-0.057^{\star \star \star \star}$ & $-0.067^{* \star \star}$ & $-0.064^{\star \star \star}$ & $-0.065^{\star \star \star}$ & $-0.061^{\star \star \star}$ \\
\hline & $(0.000)$ & $(0.000)$ & $(0.000)$ & $(0.001)$ & $(0.001)$ & $(0.001)$ & $(0.001)$ & $(0.000)$ & $(0.000)$ & $(0.000)$ & $(0.001)$ & $(0.001)$ & $(0.001)$ & $(0.001)$ \\
\hline SAT & $0.001^{\star \star \star *}$ & $0.001^{\star \star \star \star}$ & $0.001^{\star \star \star \star}$ & $0.001^{\star \star \star \star}$ & $0.001^{\star \star \star}$ & $0.001^{\star \star \star \star *}$ & $0.001^{\star \star \star *}$ & $-0.000^{\star \star \star *}$ & $-0.000^{\star \star \star *}$ & $-0.000^{* \star \star *}$ & $-0.000^{* \star * \star}$ & $-0.000^{* \star * \pi}$ & $-0.000^{* \star x}$ & $-0.000^{* \star x+}$ \\
\hline & $(0.000)$ & $(0.000)$ & $(0.000)$ & $(0.000)$ & $(0.000)$ & $(0.000)$ & $(0.000)$ & $(0.000)$ & $(0.000)$ & $(0.000)$ & $(0.000)$ & $(0.000)$ & $(0.000)$ & $(0.000)$ \\
\hline Oldest Sibling & - & $0.020^{* k+k}$ & -- & -- & -. & -. & -- & -- & $0.019^{* \star \star \star}$ & -- & -- & - & -- & -- \\
\hline & -- & $(0.001)$ & -- & -- & -- & -- & -- & -- & $(0.002)$ & -- & -- & -- & -- & -- \\
\hline Second Oldest Sibling & -- & $0.019^{* \star \star *}$ & -- & -- & -- & -- & -- & -- & $0.031^{\star \star * *}$ & -- & -- & -- & -- & -- \\
\hline & -- & $(0.001)$ & -- & -- & -- & -- & -- & -- & $(0.002)$ & -- & -- & -- & -- & -- \\
\hline Third or More Oldest Sibling & -- & $0.017^{* \star *}$ & -- & -- & -- & -- & -- & -- & $0.044^{\star \star \star *}$ & -- & -- & -- & -- & -- \\
\hline Total Number of Siblings & 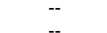 & $(0.002)$ & -- & - & -- & -- & $\ddot{--}$ & -- & $(0.003)$ & -- & -- & -- & -- & $\ddot{--}$ \\
\hline Total Number of Siblings & $\overline{-}$ & $0.006^{\star \star \star}$ & $-\overline{-}$ r & - & $-\overline{-}$ r lo & $0.007^{* k+k}$ & $0.006^{\star \star \star}$ & -- & $-0.016^{\star \star \star}$ & -- & -- & -- & $-0.011^{\star \star \star}$ & $-0.008^{\star \star \star}$ \\
\hline Years Between Siblinas & $\overline{-}$ & $(0.001)$ & $\ldots$ & -- & $\ldots$ & $(0.001)$ & $(0.001)$ & $\overline{-}$ & $(0.001)$ & -- & & -- & $(0.001)$ & $(0.001)$ \\
\hline & $-\overline{-}$ & $-\overline{-}$ & -- & -- & $\overline{-}$ & $-0.0000)$ & $-0.0000)$ & -- & - & -- & -- & -- & $0.002^{\star \star \star \star}$ & $0.002^{2 \star \star}$ \\
\hline Older Sibling Male & -. & .- & .- & .- & -- & $0.001^{*}$ & $0.012^{\star \star \star}$ & -- & -. & -- & -- & -- & 0.000 & $-0.012^{* \star \star}$ \\
\hline & .. & .. & .- & .- & .. & $(0.001)$ & $(0.001)$ & -. & -. & -. & -. & -. & $(0.001)$ & $(0.001)$ \\
\hline Older Sibling Same Sex & -- & -- & .- & .- & -. & $-0.002^{\star \star \star}$ & $-0.002^{\star \star \star}$ & -- & -- & -. & -- & -- & $0.007^{\star \star \star \star}$ & $0.007^{* \star \star}$ \\
\hline & -- & -- & -- & -- & -- & $(0.001)$ & $(0.001)$ & -- & -- & -- & -- & -- & $(0.001)$ & $(0.001)$ \\
\hline Older Sibling SAT & -- & -- & -- & -- & -- & $0.000^{\star \star \star *}$ & $-0.000^{\star \star \star *}$ & -- & -- & -- & -- & -- & $-0.000^{\star \star \star}$ & $0.000^{* \star *}$ \\
\hline & -- & -- & -- & -- & -- & $(0.000)$ & $(0.000)$ & -- & -- & -- & -- & -- & $(0.000)$ & $(0.000)$ \\
\hline Older Sibling Enrolls in Four-Year College & -- & -- & -- & -- & -- & -. & $0.174^{\star \star \star}$ & -- & -- & -- & -- & -- & -- & -- \\
\hline & ( & 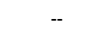 & - & -- & ( & -- & $(0.001)$ & -- & -- & .- & -- & -- & -- & -- \\
\hline Older Sibling Enrolls in Public College & -- & -- & -- & -- & -- & -- & -- & -- & -- & -- & -- & -- & -- & $0.243^{* \star *}$ \\
\hline & -. & -- & -- & -- & -. & -- & -. & -- & -- & -- & -. & -- & -- & $(0.001)$ \\
\hline Observations & $8,984,983$ & $8,984,983$ & $6,420,099$ & $1,077,989$ & $1,486,895$ & $1,486,895$ & $1,486,895$ & $8,949,472$ & $8,949,472$ & $6,392,352$ & $1,074,740$ & $1,482,380$ & $1,482,380$ & $1,482,380$ \\
\hline R-squared & 0.275 & 0.276 & 0.276 & 0.261 & 0.266 & 0.266 & 0.287 & 0.173 & 0.173 & 0.169 & 0.193 & 0.184 & 0.184 & 0.232 \\
\hline
\end{tabular}




\begin{tabular}{|c|c|c|c|c|c|c|c|c|c|c|c|c|c|c|}
\hline \multicolumn{15}{|c|}{ Table 5 - Determinants of College Selectivity } \\
\hline \multirow[b]{3}{*}{ Male } & \multicolumn{7}{|c|}{ Dependent Variable $=$ Avg. SAT of Enrolled College } & \multicolumn{7}{|c|}{ Dependent Variable $=$ Enrolls in Barron's Category 1 (most selective) } \\
\hline & \multicolumn{2}{|c|}{ All Students } & \multirow{3}{*}{$\begin{array}{c}\frac{\text { Non-Siblings }}{-0.866^{\star \star \star}} \\
(0.097)\end{array}$} & \multirow{3}{*}{ 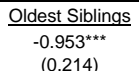 } & \multicolumn{3}{|c|}{ Younger Siblings } & \multicolumn{2}{|c|}{ All Students } & \multirow{3}{*}{ 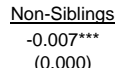 } & \multirow{3}{*}{ 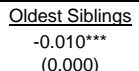 } & \multicolumn{3}{|c|}{ Younger Siblings } \\
\hline & $-1.094 \times x+2$ & $-1.123^{\star \star \star *}$ & & & $-2.153^{* \star \star}$ & $-1.749^{* * *}$ & $-2.361^{\star \star \star \star}$ & $-0.008^{x+x+x}$ & $-0.008^{* \star * *}$ & & & $-0.010^{* \star *}$ & $-0.010^{+*+*}$ & $-0.010^{* * *}$ \\
\hline Asian & $(0.080)$ & $(0.080)$ & & & $(0.185)$ & $(0.184)$ & $(0.180)$ & $(0.000)$ & $(0.000)$ & & & $(0.000)$ & $(0.000)$ & $(0.000)$ \\
\hline Asian & $\begin{array}{c}25.294^{\star \star *} \\
(0.150)\end{array}$ & 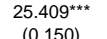 & $\begin{array}{l}26.777 * \star \star \\
(0.181)\end{array}$ & $\begin{array}{c}21.512^{\star \star \star} \\
(0.417)\end{array}$ & 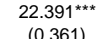 & $22.195^{\text {t*k*}}$ & 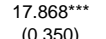 & $0.033^{\star \star *}$ & $0.033^{* \star *}$ & $0.034^{\star \star \star *}$ & $0.029^{* \star \star *}$ & $0.029^{\star \star \star}$ & $0.029^{\star * *}$ & $0.022^{* \star *}$ \\
\hline Black & $-2.300^{* * *}$ & $-1.945^{* * *}$ & $-2.983^{*+4 k}$ & $5.609^{* \star * \star}$ & $1.855^{* k+}$ & $4.581^{* \star \star *}$ & $2.313^{t+k+}$ & $0.051^{* \star *}$ & $0.051^{* * *}$ & $0.046^{* \star \star}$ & $0.070^{\star \star \star \star}$ & $0.062^{\star \star \star *}$ & $0.067^{* * * x}$ & $0.052^{\star \star \star \star}$ \\
\hline & $(0.182)$ & $(0.182)$ & $(0.206)$ & $(0.620)$ & $(0.540)$ & $(0.542)$ & $(0.528)$ & $(0.000)$ & $(0.000)$ & $(0.000)$ & $(0.001)$ & $(0.001)$ & $(0.001)$ & $(0.001)$ \\
\hline Hispanic & $12.665^{\star \star \star \star *}$ & $12.8599^{\star * *}$ & $\begin{array}{l}12.9299^{\star \star \star} \\
(0.199)\end{array}$ & $\begin{array}{c}14.056^{* * *} \\
(0.485\end{array}$ & $11.431^{1 \star \star *}$ & $12.496^{* \star *+}$ & $9.262^{\star \star \star *}$ & $0.032^{\star * \star}$ & $0.032^{2 * * *}$ & $0.029^{* * *}$ & $0.042^{+k *}$ & $0.037^{\star \star *}$ & $0.039^{* * *}$ & $0.029 * * *$ \\
\hline Other Race & $9.816^{\star \star \star *}$ & $9.969^{t+k+}$ & $10.158^{* \star \star}$ & $9.318^{\star \star \star}$ & $9.378^{\star \star \star}$ & $9.820^{* \star \star *}$ & $7.746^{\star \star \star *}$ & $0.023^{\star \star *}$ & $0.023^{* \star \star}$ & $0.022^{\star \star \star}$ & $0.024^{\star \star \star}$ & $0.023^{\star \star \star}$ & $0.024^{\star \star \star}$ & $0.019^{* \star *}$ \\
\hline & $(0.214)$ & $(0.214)$ & $(0.255)$ & $(0.587)$ & $(0.539)$ & $(0.538)$ & $(0.525)$ & $(0.000)$ & $(0.000)$ & $(0.000)$ & $(0.001)$ & $(0.001)$ & $(0.001)$ & $(0.001)$ \\
\hline Parental Income - Less Than $\$ 50,000$ & $-7.145^{* \star *}$ & $\begin{array}{l}-6.922^{\star \star *} \\
(0.144)\end{array}$ & $\begin{array}{l}-7.205 * \star * \\
(0.173)\end{array}$ & $\begin{array}{l}-8.384^{* \star *} \\
(0.396)\end{array}$ & $\begin{array}{l}-5.095^{* * *} \\
(0.379)\end{array}$ & $\begin{array}{l}-4.591^{* * *} \\
(0.378)\end{array}$ & $\begin{array}{l}-3.5577^{* * *} \\
(0.370)\end{array}$ & $\begin{array}{l}-0.007^{\star \alpha *} \\
(0.000\end{array}$ & $\begin{array}{l}-0.007^{* \alpha *} \\
(0.00)\end{array}$ & $\begin{array}{l}-0.007 * 7 * x \\
(0.00)\end{array}$ & $\begin{array}{l}-0.008^{\star \star *} \\
(0.001)\end{array}$ & $\begin{array}{l}-0.003^{\star \star \star} \\
(0.001)\end{array}$ & $-0.002^{\star \star \star}$ & $-0.002^{* *}$ \\
\hline Parental Income - $\$ 50,000$ - $\$ 100,000$ & $-9.370^{* * * *}$ & $-9.266^{\star \star * *}$ & $-8.947^{* * *}$ & $-10.998^{* * *}$ & $-9.455^{* \star \star *}$ & $-9.191^{* \star *}$ & $-7.287^{\star \star * *}$ & $-0.012^{* \star *+}$ & $-0.012^{* \star * *}$ & $-0.012^{* \star * *}$ & $-0.017^{\star * *}$ & $-0.010^{* * *}$ & $-0.010^{0 * \alpha+}$ & $-0.007^{* \star * \alpha}$ \\
\hline & $(0.119)$ & $(0.119)$ & $(0.151)$ & $(0.289)$ & $(0.272)$ & $(0.272)$ & $(0.266)$ & $(0.000)$ & $(0.000)$ & $(0.000)$ & $(0.001)$ & $(0.001)$ & $(0.001)$ & $(0.001)$ \\
\hline Parental Education - High School or Less & $\begin{array}{l}-9.5377^{\star * \star} \\
(0.136)\end{array}$ & $\begin{array}{l}-9.2877^{\star \star *} \\
(0.136)\end{array}$ & $\begin{array}{l}-9.662^{2 \star \star x} \\
(0.158)\end{array}$ & $\begin{array}{c}-7.1711^{\star \star x} \\
(0.428)\end{array}$ & $\begin{array}{c}-8.566^{* * \star} \\
(0.363)\end{array}$ & $\begin{array}{l}-6.677^{\star \star \star} \\
(0.364)\end{array}$ & $\begin{array}{l}-5.882^{\star \star *} \\
(0.357)\end{array}$ & $\begin{array}{l}0.003^{* \star x}(0) \\
(0.00)\end{array}$ & $\begin{array}{c}0.003^{* \star \star x} \\
(0.000)\end{array}$ & $\begin{array}{l}0.001 \star 1 \star x \\
(0.000)\end{array}$ & $\begin{array}{l}0.009^{\circ \star \star} \\
(0.001)\end{array}$ & $\begin{array}{l}0.006^{\star \star x} \\
(0.000)\end{array}$ & $\begin{array}{l}0.009^{\star \star \star x} \\
(0.000)\end{array}$ & $\begin{array}{l}0.008 * 0 \times * \\
(0.000)\end{array}$ \\
\hline Parental Education - Some College & $-12.232^{* * * *}$ & $-12.030^{*+* k}$ & $-12.061^{* * *+}$ & $-11.483^{* * *}$ & $-12.160^{* * *}$ & $-10.758^{* * *}$ & $-8.727^{\star \star \star \star}$ & $-0.006^{* \star *}$ & $-0.006^{\star \star * x}$ & $-0.008^{\star \star \star}$ & $-0.003^{\star \star \star}$ & $-0.003^{* \star * *}$ & $-0.001^{\star \star}$ & -0.000 \\
\hline & $(0.124)$ & $(0.124)$ & $(0.147)$ & $(0.357)$ & $(0.314)$ & $(0.314)$ & $(0.308)$ & $(0.000)$ & $(0.000)$ & $(0.000)$ & $(0.001)$ & $(0.000)$ & $(0.000)$ & $(0.000)$ \\
\hline Parental Education - Associates Degree & $-12.220 * * * x$ & $-12.031^{* *+*}$ & $-11.826^{* * *}$ & $-12.015^{* * * *}$ & $-12.817^{* * *}$ & $-11.360^{* \star * \star}$ & $-9.180^{* *+*}$ & $-0.007^{\star \star * *}$ & $-0.007^{* \star *}$ & $-0.000^{* * *}$ & $-0.004^{* * * *}$ & $-0.003^{* \star * \alpha}$ & -0.000 & 0.001 \\
\hline 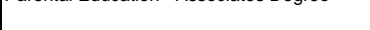 & $(0.137)$ & $(0.137)$ & $(0.164)$ & $(0.381)$ & $(0.337)$ & $(0.338)$ & $(0.332)$ & $(0.000)$ & $(0.000)$ & $(0.000)$ & $(0.001)$ & $(0.000)$ & $(0.000)$ & $(0.000)$ \\
\hline High School GPA & $50.174^{4 x+2}$ & $50.112^{k+k+1}$ & $49.587 \times \star 0 \times 10$ & $51.994^{* \times * \times}$ & $\begin{array}{c}51.100 * *+ \\
(0.213)\end{array}$ & $51.595^{\star \star \star *}$ & $49.634^{* * *}$ & $0.034^{\star \star *}$ & $0.033^{4 * \pi *}$ & $0.031^{1 \times * k}$ & $0.047^{\text {tक巾 }}$ & $0.039^{* * *}$ & $0.040^{* \star *}$ & $0.037^{\star \star \star *}$ \\
\hline SAT & $0.300^{* k+k}$ & $0.300^{* k+k}$ & $\left.0.298^{\star \star \star}\right)$ & $0.303^{* \star \star}$ & $\begin{array}{l}(0.213) \\
0.306^{* * *}\end{array}$ & 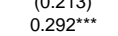 & $\begin{array}{l}\left(0.292^{* k *}\right. \\
0.21\end{array}$ & $0.000^{* * *}$ & $0.000^{* * *}$ & $\begin{array}{l}0.000^{* * *} \\
(0.0)\end{array}$ & $0.000^{* * *}$ & $0.000^{* * *}$ & $0.000^{* * *}$ & $0.000^{* * *}$ \\
\hline & $(0.000)$ & $(0.000)$ & $(0.000)$ & $(0.001)$ & $(0.001)$ & $(0.001)$ & $(0.001)$ & $(0.000)$ & $(0.000)$ & $(0.000)$ & $(0.000)$ & $(0.000)$ & $(0.000)$ & $(0.000)$ \\
\hline Oldest Sibling & -- & $0.892^{\text {*t }}$ & -- & -- & -- & -- & -- & -- & -0.001 & -- & -- & -- & -- & -- \\
\hline & -- & $(0.432)$ & -- & -- & -- & -- & -- & -- & $(0.001)$ & -- & -- & -- & -- & -- \\
\hline Second Oldest Sibling & -- & $2.784^{\star \star \star *}$ & -- & -- & -- & -- & -- & -- & $-0.005^{* \star \star}$ & -- & -- & -- & -- & -- \\
\hline & -- & $(0.439)$ & -- & -- & -- & -- & -- & -- & $(0.001)$ & -- & -- & -- & -- & -- \\
\hline Third or More Oldest Sibling & -- & $4.828^{\text {tax }}$ & -- & -- & -- & -- & -- & -- & $-0.010^{\star \star \star \star}$ & -- & -- & -- & -- & -- \\
\hline & -- & $(0.694)$ & -- & -- & -- & $\therefore$ & -- & -- & $(0.002)$ & -- & -- & -- & -- & -- \\
\hline Total Number of Siblings & -- & $0.408^{*+\ldots}$ & - & -- & -- & $0.925^{\star \star \star *}$ & $0.733^{* * *}$ & -- & $0.002^{2 * * *}$ & -- & -- & -- & $-0.001^{*}$ & $-0.001^{\star}$ \\
\hline & -- & $(0.201)$ & -- & -- & -- & $(0.199)$ & $(0.194)$ & -- & $(0.000)$ & -- & -- & -- & $(0.000)$ & $(0.000)$ \\
\hline Years Between Siblings & -- & -- & - & -- & -- & 0.046 & -0.041 & -- & -- & - & -- & -- & $-0.001^{* \star \star *}$ & $-0.001^{\star * *}$ \\
\hline & $\overline{-}$ & -- & - & - & -- & $(0.074)$ & $(0.072)$ & -- & -- & -- & -- & -- & $(0.000)$ & $(0.000)$ \\
\hline Older Sibling Male & -- & $\therefore$ & $\therefore$ & $\therefore$ & -- & $\begin{array}{l}-0.618^{\star \star *} \\
(0.14)\end{array}$ & $\begin{array}{l}1.564 * \star 1 * \\
(0.171\end{array}$ & $\because$ & - & - & -- & -- & $-0.002^{\star \star \star}$ & $0.002^{\star \star *}$ \\
\hline Older Sibling Same Sex & -. & -- & $\overline{-}$ & $-\overline{-}$ & $\overline{-}$ & $(0.174)$ & $(0.171)$ & - & -- & -- & -- & -- & $(0.000)$ & $(0.000)$ \\
\hline & -- & -- & -- & -- & -- & $\begin{array}{l}-0.981^{\star \star *} \\
(0.13)\end{array}$ & $-0.936^{\star \star * *}$ & 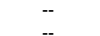 & - & - & - & $-\bar{x}$ l & $-0.001^{\star *}$ & $-0.001^{* *}$ \\
\hline Older Sibling SAT & .- & .- & .- & $\ldots$ & $\ldots$ & $0.030^{\star \star \star \star}$ & 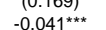 & .- & -- & $-\overline{-}$ & -- & $-\overline{-}$ & $(0.000)$ & $\begin{array}{l}(0.000) \\
-0.000^{* * *}\end{array}$ \\
\hline & -- & -. & .- & .- & .- & $(0.001)$ & $(0.001)$ & .- & .- & .- & .- & .. & $(0.000)$ & $\begin{array}{c}-0.000 \times 0 \times x \\
(0.000)\end{array}$ \\
\hline Older Sibling's Avg. SAT of Enrolled College & -- & -- & -- & -- & -- & -. & $0.217^{\star \star \star}$ & -- & -- & -- & -- & -- & $\ldots$ & - \\
\hline & -- & -- & -- & -- & -- & -- & $(0.001)$ & .- & .- & .- & .- & .- & .- & -- \\
\hline Older Sibling Enrolls in Barron's Category 1 & -- & -- & -- & -- & -- & -- & -- & -- & -- & -- & -- & -- & -- & $0.196^{\star \star *}$ \\
\hline & 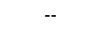 & $\ldots$ & 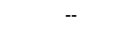 & -- & ( & 列 & - & - & $\ldots$ & $\ldots$ & - & - & -- & $(0.001)$ \\
\hline Older Sibling Enrolls in Barron's Category 2 & -- & -- & -- & -- & -- & -- & -- & -- & -- & -- & -- & -- & -- & $0.010^{* \star *}$ \\
\hline 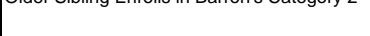 & -- & -- & -- & -- & -- & -- & -- & -- & -- & -- & -- & -- & -- & $(0.001)$ \\
\hline Older Sibling Enrolls in Barron's Category 3 & -- & -- & -- & -- & -- & -- & -- & -- & -- & -- & -- & -- & -- & $-0.001^{* * *}$ \\
\hline & -- & -- & -- & -- & -- & -- & -- & -- & -- & -- & -- & -- & -- & $(0.001)$ \\
\hline Older Sibling Enrolls in Barron's Category 4 & -- & -- & -- & -- & -- & -- & -- & -- & -- & -- & -- & -- & -- & $-0.004^{* * *}$ \\
\hline & -- & -- & -- & -- & -- & -- & -- & -- & -- & -- & -- & -- & -- & $(0.000)$ \\
\hline Older Sibling Enrolls in Barron's Category 5 & -- & -- & -- & -- & -- & -- & -- & -- & -- & -- & -- & -- & -- & $0.001^{\star}$ \\
\hline & -- & -- & -- & -- & -- & -- & -- & -- & -- & -- & -- & -- & -- & $(0.001)$ \\
\hline Older Sibling Enrolls in Barron's Category 6 & -- & -- & -- & -- & -- & -- & -- & -- & -- & -- & -- & -- & -- & $-0.003^{\star \star \star}$ \\
\hline & - & -- & - & -- & -- & -- & -- & -- & -- & -- & -- & -- & -- & $(0.001)$ \\
\hline Older Sibling Enrolls in Barron's Category 7 & - & -- & -- & -- & - & - & -- & - & - & - & -- & - & -- & $0.010^{* k+k}$ \\
\hline & - & - & - & - & - & -- & - & - & - & - & - & - & -- & $(0.002)$ \\
\hline $\begin{array}{l}\text { Observations } \\
\text { R-squared }\end{array}$ & $\begin{array}{l}6,067,413 \\
0.515\end{array}$ & $\begin{array}{l}6,067,413 \\
0.515\end{array}$ & $\begin{array}{l}4,137,518 \\
0.518\end{array}$ & $\begin{array}{l}825,863 \\
0.515\end{array}$ & $\begin{array}{c}1,104,032 \\
0.505\end{array}$ & $\begin{array}{l}1,104,032 \\
0.507\end{array}$ & $\begin{array}{l}1,104,032 \\
0.530\end{array}$ & $\begin{array}{c}9,862,921 \\
0.226\end{array}$ & $\begin{array}{c}9,862,921 \\
0.226\end{array}$ & $\begin{array}{c}7,146,981 \\
0.223\end{array}$ & $\begin{array}{l}1,127,655 \\
0.255\end{array}$ & $\begin{array}{l}1,588,285 \\
0.233\end{array}$ & $\begin{array}{c}1,588,285 \\
0.234\end{array}$ & $\begin{array}{l}1,588,285 \\
0.268\end{array}$ \\
\hline
\end{tabular}




\begin{tabular}{|c|c|c|c|c|c|c|c|c|c|c|c|c|c|}
\hline \multicolumn{14}{|c|}{ Table 6 - Determinants of Undermatch } \\
\hline \multirow[b]{3}{*}{ Male } & \multicolumn{7}{|c|}{ Dependent Variable $=$ Student SAT - Avg. SAT of Enrolled College } & \multicolumn{6}{|c|}{ Dependent Variable = Indicator if Younger Sibling SAT - Avg. SAT of Enrolled College is: } \\
\hline & \multicolumn{2}{|c|}{ All Students } & \multirow{3}{*}{ 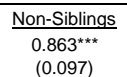 } & \multirow{3}{*}{$\begin{array}{c}\frac{\text { Oldest Siblings }}{0.953^{\star \star \star}} \\
(0.214)\end{array}$} & \multicolumn{3}{|c|}{ Younger Siblings } & \multirow{3}{*}{$\begin{array}{l}\frac{<-300}{0.006^{* \star \star}} \\
(0.000)\end{array}$} & \multirow{2}{*}{$\frac{\leq-200}{0.006^{* \star \star}}$} & \multirow{3}{*}{$\begin{array}{c}\leq-100 \\
-0.007^{* * *} \\
(0.001)\end{array}$} & \multirow{2}{*}{$\frac{>100}{0.011^{* k+}}$} & \multirow{3}{*}{$\begin{array}{l}>200 \\
0.003^{*+*} \\
(0.000)\end{array}$} & \multirow{3}{*}{$\begin{array}{l}\frac{>300}{-0.000} \\
(0.000)\end{array}$} \\
\hline & $1.094^{\star \star \star \star}$ & $1.123^{* \star *}$ & & & $2.153^{* \star * *}$ & $1.749^{* * *}$ & $2.411^{* * *}$ & & & & & & \\
\hline Asian & $(0.080)$ & $(0.080)$ & & & $(0.185)$ & $(0.184)$ & $(0.181)$ & & & & & & \\
\hline Asian & $-25.294^{\star \star *}$ & $\begin{array}{c}-25.409^{* * *} \\
(0.150)\end{array}$ & $-26.7777^{\star \star \star *}$ & $-21.512^{\star \star \star *}$ & 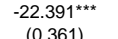 & $-22.1955^{+k+k}$ & $-19.450^{+4+\pi}$ & $0.009^{*+\pi x}$ & $0.027+4 \times+1$ & 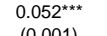 & $-0.031^{\star \star \star *}$ & $-0.014^{\star \star *}$ & $-0.004^{\star \star *}$ \\
\hline Black & $2.300^{*+*+}$ & $1.945^{\star \star *+*}$ & $2.983^{* * \star}+(1)$ & 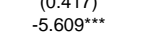 & $-1.855^{* * *}$ & $-4.581^{\star \star \star}$ & $\begin{array}{l}\left(0.387^{* \star *}\right. \\
-4.12\end{array}$ & $0.015^{\star \star \star \star}$ & $0.033^{\star \star \star *}$ & $0.033^{* * 4}$ & $0.022^{\star \star \star}$ & $0.015^{\text {kn+k}}$ & $\begin{array}{l}(0.000) \\
0.000^{*+*}\end{array}$ \\
\hline & $(0.182)$ & $(0.182)$ & $(0.206)$ & $(0.620)$ & $(0.540)$ & $(0.542)$ & $(0.531)$ & $(0.001)$ & $(0.002)$ & $(0.002)$ & $(0.001)$ & $(0.001)$ & $(0.000)$ \\
\hline Hispanic & $\begin{array}{c}-12.665^{* \star *} \\
(0.162)\end{array}$ & 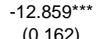 & $\begin{array}{l}-12.929^{\text {t*k }} \\
(0.189)\end{array}$ & - $14.056^{*+*+1}$ & $\begin{array}{l}-11.431^{\star * \star} \\
(0.421\end{array}$ & $-12.496^{4 x+x}$ & $-10.726^{+2 \times x}$ & $0.004^{4 * x}$ & $0.018^{+*+x}$ & $0.039+4 * x$ & $-0.013^{*+* x}$ & $-0.004^{4 * x+2}$ & $-0.001^{* * *}$ \\
\hline |Other Race & $\begin{array}{l}(0.162) \\
-9.816^{* * *}\end{array}$ & $\begin{array}{l}(0.162) \\
-9.969^{* * k}\end{array}$ & $\begin{array}{l}\text { (0.189) } \\
-10.158^{\star * \star *}\end{array}$ & $-9.318^{\star * *}$ & $\begin{array}{l}(0.421) \\
-9.378^{\star * \star}\end{array}$ & $\begin{array}{l}(0.420) \\
-9.820 \times+\times k\end{array}$ & $\begin{array}{l}(0.413) \\
-8608^{* k+k}\end{array}$ & $(0.001)$ & $(0.001)$ & $(0.002)$ & 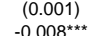 & $\begin{array}{l}(0.001) \\
-0.004^{* * *}\end{array}$ & $(0.000)$ \\
\hline & $\begin{array}{l}-1.010 \\
(0.214)\end{array}$ & $\begin{array}{l}-1.9094) \\
(0.214)\end{array}$ & $(0.255)$ & $\begin{array}{l}-9.318 \\
(0.587)\end{array}$ & $(0.539)$ & $\begin{array}{l}-1.02038) \\
(0.538)\end{array}$ & $\begin{array}{l}-8.60829) \\
(0.529)\end{array}$ & $\begin{array}{l}0.00001 \times 1 \\
(0.001)\end{array}$ & $(0.002)$ & $(0.002)$ & $\begin{array}{c}-0.008002) \\
(0.002)\end{array}$ & $\begin{array}{l}-0.0044^{4 \times 1} \\
(0.001)\end{array}$ & $\begin{array}{l}-0.000 \\
(0.001)\end{array}$ \\
\hline Parental Income - Less Than $\$ 50,000$ & $\begin{array}{c}7.145^{\star \star \star} \\
(0.144)\end{array}$ & $\begin{array}{l}6.922^{\star \star \star} \\
(0.144)\end{array}$ & $\begin{array}{c}7.205^{\star \star \star} \\
(173)\end{array}$ & $\begin{array}{l}8.384^{* \star \star *} \\
(0.396)\end{array}$ & $\begin{array}{l}5.095 * \star * \star \\
(0.379)\end{array}$ & $\begin{array}{l}4.591^{\star \star \star \star} \\
(0.378)\end{array}$ & $3.693^{3 * \star *}$ & $\begin{array}{l}0.004^{\star \star \star} \\
(0.001\end{array}$ & $\begin{array}{l}0.004 * t * x \\
(0.001)\end{array}$ & 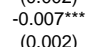 & $0.015^{* \star \star *}$ & $\begin{array}{l}0.008^{\star \star *} \\
(0.001\end{array}$ & $\begin{array}{l}0.002^{\star \star *} \\
(0.000)\end{array}$ \\
\hline Parental Income - $\$ 50,000$ - $\$ 100,000$ & $9.370^{\star \star \star}$ & $9.266^{\star \star \star}$ & $8.947^{\star \star \star}$ & $10.998^{\star \star \star}$ & $9.455^{* \star \star}$ & $9.191^{\star \star \star}$ & $7.943^{* \star \star x}$ & $-0.002^{\star \star \star}$ & $-0.008^{\star \star \star \star}$ & $-0.017^{\star \star \star \star}$ & $0.018^{\star \star \star}$ & $0.008^{\star \star \star *}$ & $0.002^{t * x}$ \\
\hline & (0.119) & $(0.119)$ & $(0.151)$ & $(0.289)$ & $(0.272)$ & $(0.272)$ & $(0.267)$ & $(0.000)$ & $(0.001)$ & $(0.001)$ & $(0.001)$ & $(0.001)$ & $(0.000)$ \\
\hline Parental Education - High School or Less & $9.537^{\star \star \star}$ & $9.287^{\star \star \star}$ & $9.662^{\star \star \star *}$ & $7.171^{\star \star \star}$ & $8.565^{\star \star \star}$ & $6.677^{\star \star \star \star}$ & $4.770^{\star \star * *}$ & $0.003^{\star \star \star \star}$ & $-0.002^{*}$ & $-0.011^{\star \star *}$ & $0.013^{\star \star \star}$ & $0.006^{* \star *}$ & $0.002^{* * *}$ \\
\hline & $(0.136)$ & $(0.136)$ & $(0.158)$ & $(0.428)$ & $(0.363)$ & $(0.364)$ & $(0.360)$ & $(0.001)$ & $(0.001)$ & $(0.002)$ & $(0.001)$ & $(0.001)$ & $(0.000)$ \\
\hline Parental Education - Some College & $\begin{array}{c}12.222^{2 \pi+k} \\
(0.124)\end{array}$ & 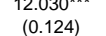 & $\begin{array}{c}12.061^{1 \times x} \\
(0.147)\end{array}$ & $\begin{array}{c}11.483^{2 \times x \times} \\
(0.357)\end{array}$ & $\begin{array}{c}12.160^{\times x \times} \\
(0.314)\end{array}$ & $\begin{array}{c}10.7588^{* \times \kappa} \\
(0.314)\end{array}$ & $\begin{array}{l}8.883^{* 11} \\
(0.311)\end{array}$ & $\begin{array}{c}-0.004^{4 \times x} \\
(0.001)\end{array}$ & $\begin{array}{c}-0.0133^{\circ \times 6} \\
(0.001)\end{array}$ & $\begin{array}{c}-0.024^{4 \times x} \\
(0.001)\end{array}$ & $\begin{array}{l}0.0015 \times 1 \times 1 \\
(0.001)\end{array}$ & $\begin{array}{l}0.006^{\circ \times 1} \\
(0.001)\end{array}$ & $\begin{array}{l}0.001^{1 \times x \times} \\
(0.000)\end{array}$ \\
\hline Parental Education - Associates Degree & $12.220^{\star \star \star \star}$ & $12.031^{\star \star \star *}$ & $11.826^{\star \star *}$ & $12.015^{\star \star \star}$ & $12.817^{\star \star \star}$ & $11.360^{* \ldots k}$ & $9.391^{\star \star \star *}$ & $-0.006^{\star \star \star}$ & $-0.016^{\star \star \star *}$ & $-0.026^{\star \star \star \star}$ & $0.014^{\star \star \star}$ & $0.005^{* \star *}$ & $0.002^{\star \star \star}$ \\
\hline 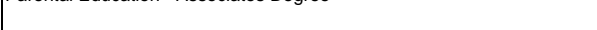 & $(0.137)$ & $(0.137)$ & $(0.164)$ & $(0.381)$ & $(0.337)$ & $(0.338)$ & $(0.334)$ & $(0.001)$ & $(0.001)$ & $(0.001)$ & $(0.001)$ & $(0.001)$ & $(0.000)$ \\
\hline High School GPA & $-50.174^{\star \star \star \star}$ & $-50.112^{\star \star \star}$ & $-49.587^{\star \star \star}$ & $-51.994^{\star \star \star}$ & $-51.100^{\star \star \star}$ & $-51.595^{\star \star \star}$ & $-50.023^{* * *}$ & $0.021^{\star \star \star}$ & $0.062^{\star \star \star}$ & $0.122^{\star \star \star}$ & $-0.092^{\star \star \star}$ & $-0.040^{\star \star *}$ & $-0.012^{\star \star \star}$ \\
\hline & $(0.088)$ & $(0.088)$ & $(0.106)$ & $(0.245)$ & $(0.213)$ & $(0.213)$ & $(0.210)$ & $(0.000)$ & $(0.001)$ & $(0.001)$ & $(0.001)$ & $(0.001)$ & $(0.000)$ \\
\hline SAT & $0.700^{\star \star \star \alpha}$ & $0.700^{\star \star \star \star}$ & $0.702^{\star \star \star}$ & $0.697 * * *$ & $0.694^{\star \star \star}$ & $0.708^{\star \star \star}$ & $0.704^{4 \star x}$ & $-0.000^{\star \star \star}$ & $-0.001^{\star \star \star \star}$ & $-0.002^{\star \star \star \alpha}$ & $0.001^{\star \star \star}$ & $0.001^{\star \star * *}$ & $0.000^{* * *}$ \\
\hline & $(0.000)$ & $(0.000)$ & $(0.000)$ & $(0.001)$ & $(0.001)$ & $(0.001)$ & $(0.001)$ & $(0.000)$ & $(0.000)$ & $(0.000)$ & $(0.000)$ & $(0.000)$ & $(0.000)$ \\
\hline Oldest Sibling & -- & $-0.892^{\star \star}$ & -- & - & -- & -- & -- & -- & -- & -- & -- & -- & -- \\
\hline & -- & $(0.432)$ & -- & -- & -- & -- & -- & -- & -- & -- & -- & -. & -- \\
\hline Second Oldest Sibling & -- & $-2.784^{\star x+k}$ & -- & -- & -- & -- & -- & -- & -- & -- & -- & -- & -- \\
\hline & -- & $(0.439)$ & -- & -- & -- & -- & -- & -- & -- & -- & -- & -- & -- \\
\hline Third or More Oldest Sibling & -- & $-4.828^{\star \star \star \star}$ & - & -- & -- & -- & -- & - & -- & -- & -- & - & - \\
\hline & -- & $(0.694)$ & -- & -- & -- & -- & -- & -- & -- & -- & -- & -- & -- \\
\hline Total Number of Siblings & -- & $-0.408^{\star \star}$ & -- & -- & -- & $-0.925^{\star \star \star}$ & $-0.668^{\star \star \star}$ & 0.000 & $0.002^{\star \star \star}$ & $0.004 * \star *$ & -0.001 & $0.001^{\star \star}$ & $0.001^{* \star}$ \\
\hline & -- & $(0.201)$ & -- & -- & -- & $(0.199)$ & $(0.195)$ & $(0.000)$ & $(0.001)$ & $(0.001)$ & $(0.001)$ & $(0.000)$ & $(0.000)$ \\
\hline Years Between Siblings & -- & -- & -- & -- & -- & -0.046 & -0.017 & -0.000 & -0.000 & 0.000 & 0.000 & 0.000 & -0.000 \\
\hline & -- & -- & -- & -- & -- & $(0.074)$ & $(0.073)$ & $(0.000)$ & $(0.000)$ & $(0.000)$ & $(0.000)$ & $(0.000)$ & $(0.000)$ \\
\hline OIder Sibling Male & -- & -- & -- & -- & -- & $0.618^{\star \star \star}$ & $-1.662^{\star * \star}$ & -0.000 & 0.000 & $0.002^{\star \star \star}$ & $-0.004^{4 \star \star \star}$ & $-0.002^{\star \star \star}$ & $-0.001^{\star \star \star}$ \\
\hline & -- & -- & -- & -- & -- & $(0.174)$ & $(0.172)$ & $(0.000)$ & $(0.000)$ & $(0.001)$ & $(0.001)$ & $(0.000)$ & $(0.000)$ \\
\hline Older Sibling Same Sex & -- & -- & -- & -- & -- & $0.981^{\star \star \star}$ & $0.968^{* * * *}$ & $0.001^{* *}$ & 0.001 & -0.001 & $0.004^{\star \star \star}$ & $0.002^{\star \star *}$ & $0.000^{\star *}$ \\
\hline & -- & -- & -- & -- & -- & $(0.173)$ & $(0.170)$ & $(0.000)$ & $(0.000)$ & $(0.001)$ & $(0.001)$ & $(0.000)$ & $(0.000)$ \\
\hline OIder Sibling SAT & -- & -- & -- & -- & -- & $-0.030^{* \star \star}$ & $-0.108^{\star \star \star *}$ & $0.000^{\star \star \star}$ & $0.000^{\star * \star}$ & $0.000^{*+* *}$ & $-0.000^{\star \star \star *}$ & $-0.000^{\star \star *}$ & $-0.000^{\star \star \star}$ \\
\hline & -- & 管 & -- & -- & -- & $(0.001)$ & $(0.001)$ & $(0.000)$ & $(0.000)$ & $(0.000)$ & $(0.000)$ & $(0.000)$ & $(0.000)$ \\
\hline OIder Sibling's SAT - Avg. SAT of Enrolled College & -- & -- & -- & -- & $-\overline{-}$ ( & -- & $0.177^{\star \star *}$ & -- & -- & -- & -- & -- & - \\
\hline Older Sibling's SAT - Avg. SAT of Enrolled College $<-300$ & -- & $-\overline{-}$ & $-\overline{-}$ & $-\overline{-}$ & -- & -- & $(0.001)$ & $0083^{* * *}$ & $0154^{* * *}$ & $-\overline{-} 67^{\star \star *}$ & $-0,-5^{* \star * k}$ & $0003 * * *$ & $0003^{* * *}$ \\
\hline Older Sibling's SAT - Avg. SAT of Enrolled College < - 300 & -- & $-\overline{-}$ & $\check{-}$ & $-\overline{-}$ & $-\overline{-}$ & $\ddot{-}$ & $-\overline{-}$ & $0.083^{* \star \star x}$ & $0.154^{\star * \star}$ & $0.167 \times \star 0 \times$ & $-0.015^{* * *}$ & $0.003^{\star \star \star *}$ & $0.003^{\star \star \star *}$ \\
\hline Older Sibling's SAT - Avg. SAT of Enrolled College $>=-300$ and $<-200$ & .- & -- & $-\overline{-}$ & -- & -- & -- & -- & $\begin{array}{l}(0.002) \\
0.030 * \star \star\end{array}$ & $\begin{array}{l}(0.003) \\
0.080^{* \star \star}\end{array}$ & $\begin{array}{l}(0.003) \\
0.124^{\star \star *}\end{array}$ & $\begin{array}{c}(0.002) \\
-0.027 \star \star 2 k\end{array}$ & $\begin{array}{c}(0.001) \\
-0.004 * \star 2\end{array}$ & $\begin{array}{l}(0.000) \\
0.001 * * *\end{array}$ \\
\hline J & -- & -- & -- & -- & -- & -. & -- & $(0.001)$ & $(0.002)$ & $(0.002)$ & $(0.001)$ & $(0.001)$ & $(0.000)$ \\
\hline Older Sibling's SAT - Avg. SAT of Enrolled College $>=-200$ and $<-100$ & -- & -- & -- & -- & -- & -- & -- & $0.007^{\star \star \star}$ & $0.032^{\star \star \star}$ & $0.068^{\star \star \star}$ & $-0.026^{\star \star \star}$ & $-0.006^{\star \star \star *}$ & -0.000 \\
\hline & -- & -- & -- & -- & -- & -- & -- & $(0.001)$ & $(0.001)$ & $(0.001)$ & $(0.001)$ & $(0.001)$ & $(0.000)$ \\
\hline Older Sibling's SAT - Avg. SAT of Enrolled College $>=100$ and $<200$ & -- & -- & - & -- & -- & -- & -- & $0.001^{\star \star \star}$ & $-0.008^{\star \star \star}$ & $-0.040^{* \star \star}$ & $0.071^{\star \star \star}$ & $0.030^{\star \star \star}$ & $0.007^{\star \star \star}$ \\
\hline & -- & -- & -- & -- & -- & -- & -- & $(0.000)$ & $(0.001)$ & $(0.001)$ & $(0.001)$ & $(0.001)$ & $(0.000)$ \\
\hline Older Sibling's SAT - Avg. SAT of Enrolled College $>=200$ and $<300$ & -- & -- & -- & -- & -- & -- & -- & $0.003^{* \star \star \star}$ & $-0.005^{\star \star * *}$ & $-0.049^{\star \star \star *}$ & $0.145^{\star \star \star *}$ & $0.081^{\star \star \star}$ & $0.025^{\star \star \star}$ \\
\hline & -- & -- & -- & -- & -- & -- & -- & $(0.000)$ & $(0.001)$ & $(0.001)$ & $(0.002)$ & $(0.002)$ & $(0.001)$ \\
\hline Older Sibling's SAT - Avg. SAT of Enrolled College >= 300 & -- & -- & -- & -- & -- & -- & -- & $0.008^{* \star *}$ & 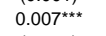 & $-0.041^{\star \star \star *}$ & $0.227^{\star \star \star \star}$ & $0.174^{* \star *}$ & $0.074^{\star \star \star *}$ \\
\hline & -- & -- & - & -- & -- & -- & -- & $(0.001)$ & $(0.001)$ & $(0.002)$ & $(0.003)$ & $(0.003)$ & $(0.002)$ \\
\hline $\begin{array}{l}\text { Observations } \\
\text { R-squared }\end{array}$ & $\begin{array}{l}6,067,413 \\
0.611\end{array}$ & $\begin{array}{l}6,067,413 \\
0.611\end{array}$ & $\begin{array}{l}4,137,518 \\
0.614\end{array}$ & $\begin{array}{c}825,863 \\
0.619\end{array}$ & $\begin{array}{l}1,104,032 \\
0.600\end{array}$ & $\begin{array}{l}1,104,032 \\
0.601\end{array}$ & $\begin{array}{l}1,104,032 \\
0.615\end{array}$ & $\begin{array}{l}1,104,032 \\
0.125\end{array}$ & $\begin{array}{l}1,104,032 \\
0.229\end{array}$ & $\begin{array}{l}1,104,032 \\
0.357\end{array}$ & $\begin{array}{c}1,104,032 \\
0.298\end{array}$ & $\begin{array}{l}1,104,032 \\
0.165\end{array}$ & $\begin{array}{c}1,104,032 \\
0.077\end{array}$ \\
\hline
\end{tabular}

